\title{
Science under attack
}

\author{
Researchers are increasingly upset with the Bush administration, not for its tactics but for its entire \\ operational philosophy.
}

Tran he highlight of the annual meeting of the American Association for the Advancement of Science (AAAS) last week was an impassioned session in which scientific leaders, including molecular biologist David Baltimore, made clear their views on the fraught relationship between science and the Bush administration.

The discussion was organized by the Union of Concerned Scientists in the wake of revelations about how the administration's political appointees have sought to control the messages communicated by scientists to the public, including attempts by the NASA press office to muzzle climate scientist James Hansen (see page 896).

And judging from the response at a packed and emotional hall in St Louis, a great many US scientists now believe that the Bush administration is prepared not only to ignore scientific facts in making policy decisions, but also to suppress findings that conflict with its own priorities.

For Baltimore - Nobel laureate, outgoing president of the California Institute of Technology, president-elect of the AAAS, and arguably the most eminent voice in all of American science - events have reached a tipping point. He suggested that the Bush administration's approach to science stems from its adherence to a particular philosophy of government, that of a 'unitary executive'. Instead of resignedly shrugging their shoulders whenever such a case of scientific manipulation arises, Baltimore argued, scientists need to recognize the potency of the threat that this governmental philosophy represents to the long-cherished independence of US science.

The unitary executive is an old idea, but not many Americans had heard of it until last month, when it cropped up during the Senate confirmation process of Supreme Court judge Samuel Alito. At the extreme, it holds that the executive branch can run the US federal government as it sees fit, especially in wartime. Given that a seminal achievement of the Constitution of the United States was to establish a balance of power between the executive branch, the Congress and the judiciary, this may sound absurd, but it seems to hold considerable sway within the Bush administration.

Baltimore warned that the doctrine opens the way for "an exertion of executive hegemony over science". He called on researchers to "fight for a very different doctrine" under which "the executive's role is to defend intellectual freedom". In the light of the Bush administration's adherence to this philosophy, he added: "It is no accident that we are seeing such an extensive suppression of science." From someone of Baltimore's experience and reputation, these are strong words.

For science to flourish it needs settings that support freedom of enquiry, and the creation of such settings was a great achievement of the Enlightenment. Protecting them is vital, not just for science but for all of humanity.

Government agencies can never provide such settings in quite the same way universities can. But their scientists must still be allowed to express the results of their research as they see fit. They should also be free
"Scientists need to recognize the potency of the threat this philosophy represents to the longcherished independence of US science." to discuss how their research makes an argument for changes in policy, as Hansen sought to do with regard to climate change. In return, scientists have to acknowledge that the line between science and policy is a fine one, and endeavour to distinguish clearly between their scientific findings and their policy ideas.

In its five years in office, the Bush administration has sought to exert tighter control of the branches of government where scientists work. This applies not only to regulatory agencies, where politics are never far below the surface, but also to places such as the National Institutes of Health and NASA, where intramural researchers are used to the freedom of expression enjoyed by their university colleagues.

It is by no means the case that these proud federal agencies or their staff have fallen subject to the executive branch's decree. Most federal agencies have a deep stock of integrity, which even eight years of the Bush administration will not erode away. Yet Congress, in particular, should be doing much more to defend them from White House interference. And researchers should stand up and be counted with colleagues in the federal government in their hour of need.

\section{Not picture-perfect}

\section{Nature's new guidelines for digital images encourage openness about the way data are manipulated.}

R esearchers struggle to amass good data and present them in as clear a fashion as possible. But what do we mean by 'clear' when it comes to images? In days gone by, whether we liked it or not, data acquired at the bench were not much different from what was published. In a biomedical lab, for example, samples that had been radio-labelled and separated on a gel were recorded on X-ray film. Composite figures were assembled, with lettering carefully placed around the mounted film. If a control was forgotten or a gel was uneven, the graduate student or postdoc was sent back into the lab to get it right 'for publication'. If a speck of dust on the film obscured data in the original photograph, another picture was taken. Slicing films to rearrange the order of samples, or to splice in a control group that was actually part of another gel, was not common because it took almost as much skill to do that as to rerun the experiment.

It is doubtful that scientists were more angelic then than now. It is 
more likely that, when it came to image manipulation, they wouldn't because they couldn't. These constraints led to the accepted standards for publishing quality images: what you got is what you saw. It's not that researchers didn't aspire to perfection - to have obtained images worthy of the admiration of colleagues enhanced your prestige because it proclaimed technical mastery. But the numerous examples of slightly inadequate data continually reminded everyone just how difficult it was not only to perform the perfect experiment, but to acquire the perfect image.

Digital image acquisition and processing tools have removed the physical impediments to perfect images and laid bare the inadequacies of current training practices. Traditions for image handling were not passed down from one generation to the next because there weren't any traditions. Into this vacuum has crept 'beautification' the digital manipulation of properly acquired data for the purpose of making a figure clearer, more perfect and more consistent with the best images yielded in such experiments. Removing dust from a digitized photo with the erasure tool, cropping bands from gels, and playing with fluorescence micrographs to enhance a particular effect are all attempts to show better results than were actually achieved in that run. In all these cases the data are legitimately acquired but then processed to yield an idealized image.

In Nature's view, beautification is a form of misrepresentation. Slightly dirty images reflect the real world. Accordingly — and after consulting with technical experts - the Nature family of journals has developed a concise guide to appropriate image handling (www.nature.com/nature/authors/submissions/images), which will soon be incorporated into Guides for Authors.

In short, any digital technique that isn't applied to the entire image is suspect and needs to be explicated to the reader in the Methods or Supplementary Information. Authors should detail the instrument settings and the software manipulation that was performed on figures in an additional table in Supplementary Information. The fewer manipulations, the easier it will be for authors, referees and readers. Any changes made to misrepresent the data in the original image (such as boosting the contrast to eliminate backgrounds, making a collage

"In short, any digital
technique that isn't applied
to the entire image is
suspect and needs to be
explicated to the reader."
of cells in a micrograph to show more cells in a visual field, or removing possibly informative bands in narrowly cropped gels) are of course strictly off limits.

We should conspire to end the fetish of the perfect image. Let's all get a little more 'real'. Nature is happy to work with others to aid the promulgation of image standards that we can all live with. The responsibilities of the institutes that train students, of the investigators who use their labour, and of the journals that publish the data can be better defined. Finding ways to regain our trust in scientific images is a goal on which we can all agree.

\section{Diplomatic incident}

\section{Japan has fumbled its row with North Korea over tests to identify abductees.}

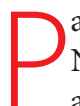
arties were held last week to celebrate the 64th birthday of North Korean leader Kim Jong-il — even in Japan, which has a troubled history with its near-neighbour. In Tokyo, the General Association of Korean Residents in Japan, which mainly comprises ancestors of Koreans who were forcibly taken to Japan during its 35-year occupation of the Korean Peninsula, held a party to mark the occasion. And those who attended were able to toast a recent diplomatic victory over Japan, in which the North Korean government was, incredibly, allowed to claim for itself the mantle of scientific objectivity.

The victory concerns the status of DNA tests conducted in Japan in 2004 on human remains that had been passed on from North Korea to Japan. North Korea said the remains were those of Megumi Yokota, a Japanese citizen that North Korea has admitted to kidnapping in 1977. Based on the DNA tests, however, Japan insists that the remains are those of someone else, and continues to demand an account of what really happened to Yokota.

But last January, in an interview with Nature, the scientist who carried out the DNA tests admitted that they were not conclusive (see Nature 433, 445; 2005). He has since been prevented from giving a full and open account of the matter.

Japan now needs to either produce evidence to back up its previous claims that the DNA tests were conclusive, or admit they weren't, perhaps as a result of a lack of DNA in the incinerated remains.

But admitting such an error is something to which Japanese officials are inherently adverse. They may fear losing face - but such a loss would only be temporary, and coming clean would strengthen Japan's position in the longer term. There would still be no solid evidence to support North Korea's claim that Yokota was cremated. Japan could then continue to press North Korea for a plausible account of what really happened to Yokota and many other kidnapped Japanese nationals.

Instead, as things stand, the issue of the DNA tests on the bones has presented Japan with a thorny diplomatic problem. And the North Koreans are taking full advantage.

At bilateral talks two weeks ago, North Korea invited Japan to arrange a joint meeting of researchers to discuss the DNA
"Japan now needs to either produce some evidence to back up its claims that the DNA tests were conclusive, or admit that they weren't." analysis. Japan declined the offer, continuing to insist that its original interpretation was correct. This left the guests at Kim's birthday party gleefully dancing on their firm scientific ground: "We just want the truth to come out," they gloated. "We want to proceed scientifically."

Japanese officials need to learn from their mistake. In jostling with Kim's unpleasant regime, they need to be sure to retain the moral high ground. Public statements based on the wrongful interpretation of scientific data are liable to backfire. Refusing to acknowledge such problems at the first available opportunity tends to compound them, resulting not just in a loss of face, but of credibility. 